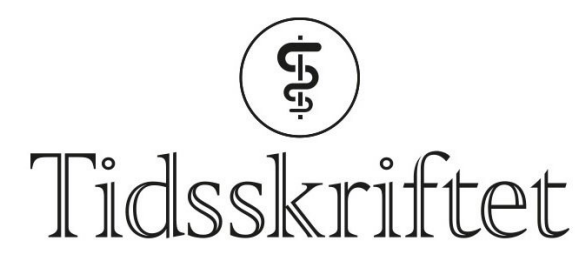

DEN NORSKE LEGEFORENING

\title{
Lille Hans
}

TIDLIGERE I TIDSSKRIFTET

\section{JULIE DIDRIKSEN}

E-post: julie.didriksen@tidsskriftet.no Tidsskriftet

Sigmund Freud anonymiserte pasientene sine. Men måten han gjorde det på, var å gi dem pseudonymer, og i ettertiden har alle pasientene fra de fem store sykehistoriene hans blitt identifisert ved sine virkelige navn. «Lille Hans», i ettertiden identifisert som Herbert Graf, sønn av den kjente musikkteoretikeren og kritikeren Max Graf(1875-1958), var kun hos Freud én gang, på grunn av en plutselig oppstått angst for hester. I en artikkel i Tidsskriftets utgave 16/1986 kunne vi blant annet lese mer om han (Tidsskr Nor Lægeforen 1986; 106: 1424-7).

\section{Hvem var Lille Hans og Ulvemannen?}

HERLUF THOMSTAD 


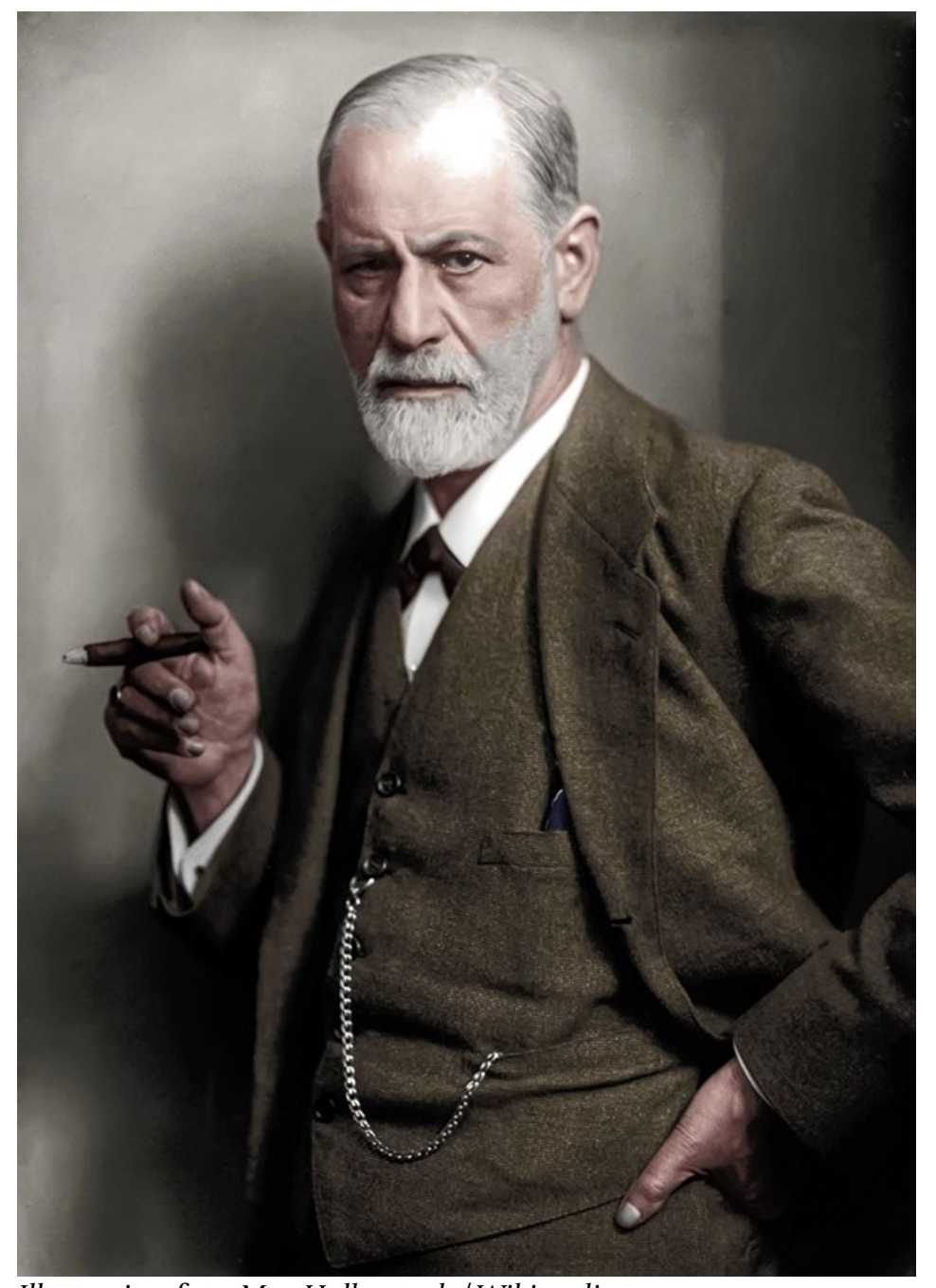

Illustrasjonsfoto: Max Halberstadt / Wikimedia commons

(...) Da Lille Hans var mellom fire og fem år, debuterte hans neurose, en angst for hester. Han var hos Freud bare én gang, og behandlingen ble fortsatt av faren eller via faren ved Freuds hjelp og veiledning. Offentliggjørelsen av denne første analyse av et barn vakte stor oppsikt og forargelse. Gutten ble spådd megen ulykke fordi han i så ung alder var blitt «berøvet sin uskyld» og gjort til offer for psykoanalysen. Ingen av disse spådommer gikk i oppfyllelse. I en etterskrift i 1922 til Analyse der Phobie eines fünfjährigen Knaben skrev Freud at våren 1922 kom en ung mann til hans kontor og sa han var Lille Hans. Freud hadde ikke sett ham eller hatt kontakt med ham på over ti år. Han fortalte at han befant seg vel, hadde ingen besvær eller hemninger. Han var kommet gjennom puberteten uten mén og hadde klart foreldrenes skilsmisse. Han fortalte også da han leste sin sykehistorie, var alt fremmed for ham. Han gjenkjente seg ikke i den.

Under sitt siste besøk i New York berettet Graf i en samtale med den unge regissør og forfatter Francis Rizzo om denne hendelse: «Da jeg var meget ung, utviklet jeg en neurotisk frykt for hester. Freud ga meg en foreløpig undersøkelse og ledet så behandlingen med min far som mellommann og brukte en slags spørsmål-og-svar spill som senere ble standard praksis i barnepsykiatri. Freud dokumenterte min helbredelse i sin artikkel fra 1909: Analyse av en femårig gutts fobi, og som den første anvendelse av psykoanalytisk teknikk ved barndomsneurose er Lille Hans som den populært kalles, fremdeles en klassisk studie i feltet. Jeg husket intet av alt dette før mange år senere da jeg kom over artikkelen i min fars arbeidsrom og kjente igjen noen av de navn og steder Freud hadde latt være uforandret. I en tilstand av sterk opphisselse oppsøkte jeg den store lege i hans Berggassé-kontor og presenterte meg selv som Lille Hans. Som han satt der bak bordet, så Freud ut som bystene av de skjeggete greske filosofer jeg hadde sett på skolen. Han reiste seg og omfavnet meg varmt og sa at han kunne ikke ha ønsket seg en bedre rettferdiggjørelse av sine teorier enn å se den lykkelige, sunne 19-åringen jeg var blitt.» 
Som han satt der bak bordet, så Freud ut som bystene av de skjeggete greske filosofer jeg hadde sett på skolen

I en samtale med Rizzo beretter Graf ellers om sitt profesjonelle liv og sin karriere i Europa og USA, der Metropolitan Opera House var hans hovedarbeidssted.». (...) Graf var ikke bare en meget habil opera- og teaterinstruktør, men også ofte fornyende og skapende. Graf arbeidet sammen med tidens største dirigenter og sangere. Kirsten Flagstad sang under hans sceneinstruksjon. (...)

Fra 1965 var han sjef for Le Grand Théâtre i Gèneve og senere for det nye Centre Lyrique. Han døde i 1973, fem dager før han ville ha fylt 70 år. (...)

Faren, Max Graf, var en venn av Freud og hørte til hans «onsdagsklubb». I en interessant artikkel om sine erindringer om Freud skriver han også at da sønnen (Herbert) ble født, spekulerte han på om han kunne beskytte ham mot det herskende antisemittiske hat $\mathrm{i}$ Wien ved å la ham vokse opp i den kristne tro. Freud frarådet ham dette. «Hvis du ikke lar din sønn vokse opp som en jøde vil du berøve ham de energikilder som ikke kan erstattes med noe annet. Han må kjempe som en jøde og du må utvikle i ham all den energi han vil trenge for den kamp. Berøv ham ikke den fordel.» Vi får ellers vite i denne artikkel at Freud tok del i Graf-familiens liv, og i forbindelse med sønnens treårs fødselsdag kom han selv opp de fire trapper med en gyngehest til gutten. Graf nevner intet om sønnens neurose og behandlingen av den. (...)

Publisert: 1. februar 2021. Tidsskr Nor Legeforen. DOI: 10.4045/tidsskr.20.0938

(C) Tidsskrift for Den norske legeforening 2020. Lastet ned fra tidsskriftet.no 